\title{
The Economic Consequences of Labor Mobility
}

\author{
By: Christopher J. Ruhm
}

Ruhm, C. (1987). The Economic Consequences of Labor Mobility. Industrial and Labor

Relations Review, Vol. 41(1): 30-42.

\begin{abstract}
:
Unlike most previous research on the relative changes in earnings of job stayers and job changers, this study examines the variance in earnings changes rather than simply average changes, men and women rather than only men, and the five-year period following job change rather than only the first year or two. The author finds great variability in earnings changes both within and across race and gender groups. Notably, men gained more from quits and, except in the case of low-wage workers, lost less from layoffs than women. Also, men suffered a much smaller penalty than women for repeated job changes. For all groups, the percentage difference between earnings before and after leaving a job generally persisted for several years.
\end{abstract}

\section{Article:}

This paper examines the impact of labor mobility on subsequent earnings. The effects of turnover are important to consider in developing policies concerned with structural economic change and have been increasingly studied in the last decade. ${ }^{1}$ National concern has focused particularly on the plight of displaced workers, leading to the establishment of such government programs as the Trade Adjustment Assistance Act of 1974 and Title III of the 1983 Job Training Partnership Act. Outcomes of voluntary labor mobility are also of interest for determining whether quitters have realistic expectations about post-separation employment. Since workers voluntarily change jobs when they expect to improve their employment situation, a basic question is whether quits lead to better (or at least no worse) jobs.

Research on mobility also provides one test of competing labor market theories. For example, as I have argued elsewhere (Ruhm 1986), models emphasizing employer-employee job matches or unobserved productivity differences predict a much stronger relationship between postseparation wages and previous tenure than does standard human capital theory.

Several issues that have not received adequate attention in previous work are addressed in this paper. First, I consider whether the average earnings changes of job changers-the measure emphasized in most previous studies - adequately summarize the effects of mobility; if not, greater attention should be paid to the variance of outcomes. Second, I attempt to determine whether turnover-induced wage changes are transitory or lasting, whereas previous studies have generally focused on only the first year or two after the separation. If subsequent wage changes are short-lived, policy makers need be less concerned about the potentially deleterious consequences of layoffs; similarly, voluntary mobility becomes less important as a mechanism for job improvement. Third, the impact of multiple separations on wages is studied in an attempt to discover whether stable post-turnover employment is associated with higher subsequent earnings growth. This examination is important given evidence (Ruhm 1987a, 1987b) that mobility sometimes reduces the stability of future employment.

1. For example, see Jenkins and Montmarquette (1979), Jacobsen (1984), Hamermesh (1984), or Podgursky and Swaim (1987). 
Fourth, since the mobility decision is endogenous, depending upon preseparation wages and expected wage changes, I examine the relationship between earnings growth and subsequent rates of turnover. This examination reduces or eliminates the bias present in most previous work, which implicitly assumes that separations occur independently of prior or expected future wage growth. Finally, I investigate how the effects of mobility differ by race and gender. Although racial differences have received some attention previously, most earlier work has been restricted to men. ${ }^{2}$

Data for this study are from the 1969 through 1980 waves of the Michigan Panel Study of Income Dynamics. As with the earlier work, cited above, I observe whether individuals separate from jobs in a base period and then compare the rates of subsequent wage changes of job stayers and job leavers. This paper substantially improves on most previous studies of this subject, however, by following individuals over a much longer period after the separation (five years) and by providing more symmetrical treatment of men and women. The extended time period partially insulates the estimates of separation-induced earnings changes from the influence of transitory reductions occurring during brief training or probationary periods and also provides information on the time path of post- turnover earnings changes.

\section{DATA AND SAMPLE CHARACTERICES}

To examine the impact of quits and layoffs on subsequent earnings, in this paper I compare the weekly real wage rates and annual incomes of heads of households in each of the seven base years 1969 through 1975 to corresponding earnings in the five years that follow. ${ }^{3}$ The base year is denoted as year zero and the following as years one through five. ${ }^{4}$ Heads of households are included in the sample if they were between eighteen and sixty years old in the base year and participated in the labor force during some part of each of years zero through five. The sample includes 14,372 observations for men and 2,137 for women. Workers are classified as job stayers and voluntary or involuntary job changers according to whether they permanently separated from jobs during the first year after the base year. ${ }^{5}$ Earnings changes are calculated as ratios of weekly real wages in years one through five to real wages at time zero. ${ }^{6}$

2. Blau and Kahn (1981a,b) and Borjas (1984) look at racial differences. Recent examples of studies concentrating exclusively on the turnover of men are Mincer and Jovanovic (1981), Antel (1985), and Gottschalk and Maloney (1985).

3. The beginning and ending base years were chosen to make greatest use of the available data. 1969 is the first year for which information on all the variables became available. The PSID revised the question on job seniority in 1976, making it difficult to compare reported tenure before and after that year.

4. For example, if the base year is 1972, 1974 corresponds to year two, 1975 to year three, and so on.

5. Data are self-reported by the survey recipient (or occasionally by another family member). Therefore, some quits may actually be disguised layoffs, and vice-versa. For example, an individual may be offered the opportunity to "voluntarily" leave a job to avoid having an "involuntary" termination on his or her record. These problems are common to all studies using self-reported data.

A further shortcoming of annual retrospective data such as the PSID is that they do not permit us to distinguish between direct movement from a quit or layoff to another job and movement from a job to unemployment before taking another job, since the PSID asks only for employment status on the survey date and joblessness may occur between the annual surveys. Unfortunately, data sources that do permit 
Table 1. Selected Sample Means.

\begin{tabular}{|c|c|c|}
\hline Variable & Men & Women \\
\hline Age (years) & 38.5 & 42.1 \\
\hline Experience (years) & 19.6 & 18.1 \\
\hline Married & $94.0 \%$ & $2.1 \%$ \\
\hline Nonwhite & $28.7 \%$ & $61.3 \%$ \\
\hline $\begin{array}{l}\text { Education } \\
\text { High School or Less } \\
\text { Some College } \\
\text { College Graduate }\end{array}$ & $\begin{array}{l}59.0 \% \\
25.4 \% \\
15.6 \%\end{array}$ & $\begin{array}{l}67.6 \% \\
22.7 \% \\
9.7 \%\end{array}$ \\
\hline $\begin{array}{l}\text { City Size } \\
<25,000 \\
25,000-100,000 \\
>100,000\end{array}$ & $\begin{array}{l}24.6 \% \\
19.0 \% \\
56.4 \%\end{array}$ & $\begin{array}{l}9.6 \% \\
13.4 \% \\
77.0 \%\end{array}$ \\
\hline $\begin{array}{l}\text { Tenure (years) } \\
<3 \\
\quad 3-10 \\
>10\end{array}$ & $\begin{array}{l}22.0 \% \\
46.2 \% \\
31.3 \%\end{array}$ & $\begin{array}{l}22.6 \% \\
52.6 \% \\
24.3 \%\end{array}$ \\
\hline $\begin{array}{l}\text { Earnings and Weeks } \\
\text { Worked } \\
\text { Annual Income } \\
\text { Weekly Wages } \\
\text { Weeks Worked }\end{array}$ & $\begin{array}{r}\$ 10,880 \\
\$ 229 \\
47.4\end{array}$ & $\begin{array}{l}\$ 5,480 \\
\$ 119 \\
45.8\end{array}$ \\
\hline $\begin{array}{l}\text { Separation Probabilitie } \\
\text { Voluntary } \\
\text { Involuntary }\end{array}$ & $\begin{array}{l}4.7 \% \\
8.8 \%\end{array}$ & $\begin{array}{l}4.4 \% \\
8.2 \%\end{array}$ \\
\hline$N$ & 14,372 & 2,137 \\
\hline $\begin{array}{l}\text { Note: The sample i } \\
\text { hold and all variables } \\
\text { a Separation probat } \\
\text { workers leaving jobs } \\
\text { year following year z } \\
\text { Source: Calculated f } \\
\text { Michigan Panel Study }\end{array}$ & $\begin{array}{l}\text { icted to he } \\
\text { easured in } \\
\text { show the } \\
\text { e specified } \\
\text { he } 1969 \text { - } 80 \\
\text { ome Dymami }\end{array}$ & $\begin{array}{l}\text { s of house- } \\
\text { e year zero. } \\
\text { rcentage of } \\
\text { ason in the } \\
\text { aves of the }\end{array}$ \\
\hline
\end{tabular}

Table 1 presents the mean characteristics of the subsamples of men and women. Note that the women sampled are not typical of the female work force. Rather, they are older, more experienced, and less likely to be white, married, or living in small towns. Their job tenure is only slightly shorter than for the male subsample, and they earn 52.0 percent (50.4 percent) of male weekly wages (annual incomes), which is considerably lower than the earnings ratio for all working women.

this distinction (for example, the Current Population Survey) do not allow us to track individuals over extended time periods.

A separation is classified as permanent if the individual fails to return to his or her former employer within two years.

6. For example, $W_{C H G} 4=\left(W_{4}-W_{0}\right) / W_{0}$, where $W_{0}$ and $W_{4}$ are weekly real wages in years zero and four. An additional analysis for annual income changes yielded results quite similar to those for wage changes.

It would be best to use data on total compensation, including fringe and other nonwage benefits. The absence of data on nonwage compensation in this study, as in most similar studies, may lead to an understatement of the costs of mobility, especially for older and high-tenure workers, who may lose pension benefits.

7. The female/male wage ratio for year-round full-time workers was 0.59 for whites and 0.70 for nonwhites in 1970 (Hamermesh and Rees 1984:331). 
The special characteristics of included women result from two factors. First, female workers who are household heads are more attached to the labor force than other female workers, and thus have higher average experience, tenure, and educational levels. Second, since women are classified as household heads only when no adult man is present, unmarried and nonwhite women are over-represented. Because these women are disproportionately nonwhite, they also frequently reside in large cities and have relatively low earnings. It would be desirable to include data on non-household heads, but information on such workers is quite limited in the PSID. To make the samples more comparable, groups of men and women with relatively similar earnings are considered below.

Table 2 summarizes average wage growth between year zero and years two and four. ${ }^{8}$ The most striking result is the extreme variance of outcomes. For example, between years zero and two, weekly wages grow more than 10 percent among almost half of all voluntary job changers, but fall an equivalent amount for nearly a third (31.5 percent of men, 29.3 percent of women) of this group.

Immobile workers have the smallest dispersion of wage changes and are least likely to experience large reductions in earnings. For instance, male job stayers are less than half as likely as their mobile counterparts to suffer decreases in weekly wages of 25 percent or more. Even so, approximately a fifth of male job stayers lose 10 percent or more, in real terms, and two-fifths gain a similar amount.

Table 2. Changes in Weekly Wages by Gender and Separation Status.

\begin{tabular}{|c|c|c|c|c|c|c|}
\hline \multirow[b]{3}{*}{ Wage Change } & \multicolumn{3}{|c|}{ Men } & \multicolumn{3}{|c|}{ Women } \\
\hline & \multirow{2}{*}{$\begin{array}{l}\text { Job } \\
\text { Stayer }\end{array}$} & \multicolumn{2}{|c|}{ Job Changer } & \multirow{2}{*}{$\begin{array}{c}\text { Job } \\
\text { Stayer }\end{array}$} & \multicolumn{2}{|c|}{ Job Changer } \\
\hline & & VOL & INVOL & & VOL & INVOL \\
\hline \multicolumn{7}{|l|}{ Year 2} \\
\hline $\begin{array}{l}\geq 10 \% \\
-10 \% \text { to } 10 \% \\
-25 \% \text { to }-10 \% \\
<-25 \%\end{array}$ & $\begin{array}{l}37.6 \% \\
41.3 \\
13.2 \\
7.9\end{array}$ & $\begin{array}{l}45.4 \% \\
23.1 \\
13.3 \\
18.2\end{array}$ & $\begin{array}{l}30.2 \% \\
25.5 \\
19.2 \\
25.1\end{array}$ & $\begin{array}{l}40.8 \% \\
36.9 \\
12.0 \\
10.3\end{array}$ & $\begin{array}{l}45.4 \% \\
25.3 \\
9.8 \\
19.5\end{array}$ & $\begin{array}{l}48.3 \% \\
16.9 \\
13.5 \\
21.4\end{array}$ \\
\hline \multicolumn{7}{|l|}{ Year 4} \\
\hline $\begin{array}{l}\geq 10 \% \\
-10 \% \text { to } 10 \% \\
-25 \% \text { to }-10 \% \\
<-25 \%\end{array}$ & $\begin{array}{l}46.1 \% \\
32.0 \\
12.5 \\
9.5\end{array}$ & $\begin{array}{l}54.5 \% \\
20.0 \\
9.4 \\
16.1\end{array}$ & $\begin{array}{l}40.3 \% \\
20.6 \\
14.7 \\
24.4\end{array}$ & $\begin{array}{l}48.3 \% \\
27.6 \\
12.2 \\
11.9\end{array}$ & $\begin{array}{l}47.7 \% \\
20.7 \\
10.9 \\
20.7\end{array}$ & $\begin{array}{l}39.8 \% \\
21.5 \\
12.9 \\
25.8\end{array}$ \\
\hline
\end{tabular}

${ }^{\mathrm{a}}$ The percentage difference in real weekly earnings between the base year (period zero) and two or four years later.

8. Wage changes were also calculated for years one, three, and five, and the results show patterns similar to those reported above. Most of the discussion is limited to years two or four to save space. I have not controlled for selection bias, which occurs when individuals are excluded from the sample due to a full year of nonemployment. That bias is unlikely to be large, since only a very small proportion of the sample is excluded. For instance, in year two, 0.6 percent of men and of women are excluded, and in year four, 0.7 percent of men and 0.8 percent of women were excluded. 
Men who quit jobs gain relative to those who are involuntarily released. The averages, however, conceal a wide variation of outcomes. Quitters frequently earn lower wages in their new job than in preseparation employment, and although earnings reductions are more probable for involuntary job leavers (44.3 percent of layoffs, compared to 31.5 percent of voluntary separations, result in earnings reductions of 10 percent or more), almost a third of permanently laid-off workers obtain 10 percent or larger wage increases by year two. Type of job mobility is an even less useful predictor of wage changes for women. Layoffs are more likely than quits to lead to 10 percent or larger wage losses (34.9 percent versus 29.3 percent), but they just as frequently result in earnings increases, and are only slightly more often associated with decreases exceeding 25 percent.

The second four rows of Table 2 detail growth in weekly wages occurring between years zero and four (three years after mobility). The variance of wage growth observed through year two persists and, if anything, actually increases. For example, the percentage of workers with wage changes exceeding 10 percent of year zero earnings (either gains or losses) is larger than in year two for every group except laid-off women. This finding suggests that initial wage changes persist for consider able periods of time. ${ }^{9}$ I return to the question of persistence below.

\section{DETERMINANTS OF WAGE CHANGES}

In addition to the source of mobility, earnings depend on individual attributes such as age, education, and job tenure. I employ two models to estimate how these characteristics affect wage growth. The first is

$$
\mathrm{WCHGT}=\beta X_{0}+\gamma \mathrm{SEP}_{1}+\epsilon_{\mathrm{t}}
$$

where WCHGT indicates the percent wage between years zero and $\mathrm{T}, X$ is a vector of control characteristics, SEP a vector of dummy variables indicating voluntary or involuntary separations in year one, $\in$ a white noise error term, and subscripts indicate the year. Equation (1) is separately estimated for men and women. To ascertain how the influence of individual characteristics (such as race) varies across separation groups, I also estimate

$$
\mathrm{WCHGT}=\beta X_{0}+\epsilon_{\mathrm{t}}
$$

for subsamples of job stayers, quitters, and involuntary changers.

The control vector $X$ includes age, age squared, experience, experience squared, and dummy variables for job tenure, race, education, city size, and the survey year. Information on actual work experience is available for 1974, so experience is calculated as 1974 experience plus the number of years since 1974. Data restrictions require use of dummy variables for education and job tenure. ${ }^{10}$ Weekly wages and annual incomes are adjusted for price changes using the GNP deflator.

9. Alternatively, the variance could result from large (random) year-to-year wage changes for individuals.

10. Both age and experience are included in the regressions. Despite potential collinearity, $t$ statistics are frequently statistically significant, indicating independent effects of age and experience. Calculating job tenure is somewhat complicated, since the PSID collects tenure information only for persons employed at the time of the survey. Constructing the tenure variable, therefore, often involves using data from one or two years prior to year zero. 
Columns 1 and 5 in Table 3 show results of equation (1), where the dependent variable wCHG4 equals $\left(W_{4}-W_{0}\right) / W O$, with $W_{t}$ the real wage in year $t$. Regression coefficients for wage or income growth in other years are similar to those reported in the table. Because most of the findings have been the subject of previous research, I will discuss them only briefly.

Wage profiles flatten with increasing experience for men but have a constant slope for women and grow approximately 5 percent faster for nonwhites than for whites between years zero and four. ${ }^{11}$ Negative coefficients on the tenure variables indicate concave seniority/wage profiles, with more extreme flattening for men than for women. ${ }^{12}$ Wages grow faster for residents of small towns than for residents of large cities and for less educated persons than for university graduates. $^{13}$

Finally, separations have a more clear-cut impact on men's earnings than on women's. Men who voluntarily leave their jobs enjoy 10.5 percent faster wage growth than job stayers, and men who leave involuntarily suffer 13.6 percent slower wage growth. Surprisingly, neither type of mobility has a statistically significant impact on wage growth for women, and there is no evidence that permanent layoffs lead to more adverse consequences than quits. Although women's earnings grow faster than men's (18.2 percent versus 16.1 percent), job improvement through voluntary mobility appears to be primarily a male prerogative. ${ }^{14}$ Conversely, women appear to be hurt less by involuntary layoffs.

Columns 2-4 and 6-8 show results for equation (2) with wCHG4 as the dependent variable. Age and experience have only a small effect on male wage growth rates but are more important for women. For instance, adding ten years to the average male age and experience (38.5 years and 19.6 years, respectively) affects expected wage growth by a factor of 1.54 percent, 0.96 percent, and -3.34 percent for job stayers, voluntary quitters, and laid-off workers, respectively. When ten years is added to the age and experience averages for women (42.1 years and 18.1 years, respectively), the corresponding figures are -6.97 percent, -18.70 percent, and 3.55 percent. $^{15}$

Although overall wage growth is faster for nonwhites than whites, Table 3 reveals considerable differences in the relative gain across separation categories. Earnings of nonwhite male job

11. See Blinder (1973) and Duncan and Hoffman (1979) for similar findings on experience and Freeman (1981) for evidence of shrinking racial differentials during the period studied.

12. Direct regressions on log wages confirm this result. One explanation is that after controlling for such characteristics as experience and tenure, women receive less on-the-job training than men (Corcoran and Duncan 1979).

13. The reduction of the education wage premium is widely documented. For instance, Freeman (1980) finds that male college graduates earned 50 percent more than their high school-educated peers in 1967 but only 34 percent more a decade later.

14. The faster wage growth of women is peculiar to my sample and probably results from the high sample proportion of nonwhites, combined with an improving female/male earnings ratio for this group. (Between 1970 and 1980, the female/male earnings ratio of all full-time workers improved from 0.70 to 0.76 for nonwhites but slightly worsened for whites [Flamermesh and Rees 1984: 334].)

15. $F$ tests indicate that the joint impact of age and experience is statistically significant for all categories of men and for female job stayers. The coefficients are not statistically significant for mobile women due to small sample sizes. 
Table 3. Effects of Individual Characteristics, Gender, and Separation Status on Percent Wage Change (WCHG4). ${ }^{a}$

\begin{tabular}{|c|c|c|c|c|c|c|c|c|}
\hline & \multicolumn{4}{|c|}{ Men } & \multicolumn{4}{|c|}{ Women } \\
\hline & \multirow{2}{*}{$\begin{array}{c}\text { All } \\
\text { Workers }\end{array}$} & \multirow{2}{*}{$\begin{array}{c}\text { Job } \\
\text { Stayers }\end{array}$} & \multicolumn{2}{|c|}{ Job Changers } & \multirow{2}{*}{$\begin{array}{c}\text { All } \\
\text { Workers }\end{array}$} & \multirow{2}{*}{$\begin{array}{l}\text { Job } \\
\text { Stayers }\end{array}$} & \multicolumn{2}{|c|}{ Job Changers } \\
\hline & & & VOL & INVOL & & & VOL & INVOL \\
\hline $\mathrm{AGE}$ & $\begin{array}{l}-0.042^{*} \\
(-3.94)\end{array}$ & $\begin{array}{l}-0.053^{*} \\
(-5.16)\end{array}$ & $\begin{array}{l}0.043 \\
(0.67)\end{array}$ & $\begin{array}{c}0.018 \\
(0.54)\end{array}$ & $\begin{array}{c}0.012 \\
(0.98)\end{array}$ & $\begin{array}{c}0.005 \\
(0.41)\end{array}$ & $\begin{array}{c}0.072 \\
(1.11)\end{array}$ & $\begin{array}{l}-0.235 \\
(-1.85)\end{array}$ \\
\hline AGESQ & $\begin{array}{l}6.6 \mathrm{E}-4 * \\
(5.08)\end{array}$ & $\begin{array}{l}8.0 \mathrm{E}-4^{*} \\
(6.38)\end{array}$ & $\begin{array}{l}-4.4 \mathrm{E}-4 \\
(-0.52)\end{array}$ & $\begin{array}{l}-1.2 \mathrm{E}-4 \\
(-0.28)\end{array}$ & $\begin{array}{c}-1.9 \mathrm{E}-4 \\
(-1.26)\end{array}$ & $\begin{array}{l}-1.0 \mathrm{E}-4 \\
(-0.68)\end{array}$ & $\begin{array}{l}-9.0 \mathrm{E}-4 \\
(-1.06)\end{array}$ & $\begin{array}{l}2.5 \mathrm{E}-3 \\
(1.63)\end{array}$ \\
\hline EXP & $\begin{array}{c}-0.007 \\
(-1.17)\end{array}$ & $\begin{array}{c}0.002 \\
(0.32)\end{array}$ & $\begin{array}{c}-0.064 \\
(-1.93)\end{array}$ & $\begin{array}{l}-0.036^{*} \\
(-2.02)\end{array}$ & $\begin{array}{c}0.003 \\
(0.48)\end{array}$ & $\begin{array}{l}0.004 \\
(0.62)\end{array}$ & $\begin{array}{c}0.003 \\
(0.09)\end{array}$ & $\begin{array}{c}0.059 \\
(0.92)\end{array}$ \\
\hline EXPSQ & $\begin{array}{l}-2.1 \mathrm{E}-4 \\
(-1.69)\end{array}$ & $\begin{array}{l}-4.0 \mathrm{E}-4 * \\
(-3.30)\end{array}$ & $\begin{array}{l}1.2 \mathrm{E}-3 \\
(1.47)\end{array}$ & $\begin{array}{l}4.9 \mathrm{E}-4 \\
(1.32)\end{array}$ & $\begin{array}{l}-1.2 \mathrm{E}-4 \\
(-0.82)\end{array}$ & $\begin{array}{l}-1.4 \mathrm{E}-4 \\
(-0.97)\end{array}$ & $\begin{array}{l}-1.8 \mathrm{E}-4 \\
(-0.18)\end{array}$ & $\begin{array}{l}-1.3 \mathrm{E}-3 \\
(-0.83)\end{array}$ \\
\hline RACE & $\begin{array}{l}0.048^{*} \\
(3.49)\end{array}$ & $\begin{array}{l}0.055^{*} \\
(4.16)\end{array}$ & $\begin{array}{c}0.013 \\
(1.47)\end{array}$ & $\begin{array}{c}-0.006 \\
(-0.14)\end{array}$ & $\begin{array}{c}0.058 \\
(1.92)\end{array}$ & $\begin{array}{c}0.027 \\
(0.91)\end{array}$ & $\begin{array}{c}0.113 \\
(0.80)\end{array}$ & $\begin{array}{c}0.368 \\
(1.78)\end{array}$ \\
\hline TEN1 & $\begin{array}{l}-0.073^{*} \\
(-4.75)\end{array}$ & $\begin{array}{l}-0.077 * \\
(-5.03)\end{array}$ & $\begin{array}{c}-0.044 \\
(-0.56)\end{array}$ & $\begin{array}{l}-0.045 \\
(-1.08)\end{array}$ & $\begin{array}{c}-0.063^{*} \\
(2.00)\end{array}$ & $\begin{array}{c}-0.042 \\
(-1.33)\end{array}$ & $\begin{array}{l}-0.436^{*} \\
(-3.03)\end{array}$ & $\begin{array}{l}0.536^{* *} \\
(2.45)\end{array}$ \\
\hline TEN2 & $\begin{array}{l}-0.087 * \\
(-4.85)\end{array}$ & $\begin{array}{l}-0.087 * \\
(-5.00)\end{array}$ & $\begin{array}{l}-0.205 \\
(-1.57)\end{array}$ & $\begin{array}{c}-0.076 \\
(-1.13)\end{array}$ & $\begin{array}{l}-0.138^{*} \\
(-3.55)\end{array}$ & $\begin{array}{l}-0.117 * \\
(-3.13)\end{array}$ & $\begin{array}{c}-0.477 \\
(-1.82)\end{array}$ & $\begin{array}{c}0.010 \\
(0.033)\end{array}$ \\
\hline ED 1 & $\begin{array}{c}0.016 \\
(1.07)\end{array}$ & $\begin{array}{c}0.007 \\
(0.50)\end{array}$ & $\begin{array}{c}0.083 \\
(0.98)\end{array}$ & $\begin{array}{c}0.035 \\
(0.70)\end{array}$ & $\begin{array}{c}0.041 \\
(1.25)\end{array}$ & $\begin{array}{c}0.057 \\
(1.79)\end{array}$ & $\begin{array}{c}0.003 \\
(0.02)\end{array}$ & $\begin{array}{c}0.259 \\
(0.93)\end{array}$ \\
\hline ED2 & $\begin{array}{c}-0.018 \\
(-0.94)\end{array}$ & $\begin{array}{c}-0.021 \\
(-1.16)\end{array}$ & $\begin{array}{c}0.024 \\
(0.20)\end{array}$ & $\begin{array}{c}-0.152 \\
(-1.92)\end{array}$ & $\begin{array}{c}-0.081 \\
(-1.71)\end{array}$ & $\begin{array}{c}-0.061 \\
(-1.34)\end{array}$ & $\begin{array}{c}-0.392 \\
(-1.67)\end{array}$ & $\begin{array}{l}-1.210 \\
(-1.42)\end{array}$ \\
\hline URB 1 & $\begin{array}{c}-0.025 \\
(-1.63)\end{array}$ & $\begin{array}{c}-0.027 \\
(-1.81)\end{array}$ & $\begin{array}{c}0.013 \\
(0.14)\end{array}$ & $\begin{array}{c}-0.039 \\
(-0.75)\end{array}$ & $\begin{array}{c}-0.064 \\
(-1.72)\end{array}$ & $\begin{array}{c}-0.022 \\
(-0.59)\end{array}$ & $\begin{array}{r}-0.307 \\
(-1.64)\end{array}$ & $\begin{array}{l}-0.009 \\
(-0.03)\end{array}$ \\
\hline URB2 & $\begin{array}{c}-0.018 \\
(0.025)\end{array}$ & $\begin{array}{l}0.047^{*} \\
(2.76)\end{array}$ & $\begin{array}{c}-0.081 \\
(-0.73)\end{array}$ & $\begin{array}{c}0.032 \\
(0.54)\end{array}$ & $\begin{array}{l}0.143^{*} \\
(3.73)\end{array}$ & $\begin{array}{l}0.176^{*} \\
(3.47)\end{array}$ & $\begin{array}{l}-0.018 \\
(-0.07)\end{array}$ & $\begin{array}{l}1.25)^{*} \\
(3.15)\end{array}$ \\
\hline VOL & $\begin{array}{l}0.105^{*} \\
(4.95)\end{array}$ & & & & $\begin{array}{c}0.026 \\
(0.54)\end{array}$ & & & \\
\hline INVOL & $\begin{array}{l}-0.136^{*} \\
(-4.85)\end{array}$ & & & & $\begin{array}{c}0.047 \\
(0.77)\end{array}$ & & & \\
\hline ADJ RSQ & 0.026 & 0.025 & 0.018 & 0.046 & 0.047 & 0.043 & 0.066 & 0.282 \\
\hline DEP MEAN & 0.161 & 0.150 & 0.319 & 0.072 & 0.182 & 0.174 & 0.224 & 0.260 \\
\hline $\mathrm{N}$ & $\begin{array}{c}14,212 \\
(1)\end{array}$ & $\begin{array}{c}12,304 \\
(2)\end{array}$ & $\begin{array}{c}1,244 \\
(3)\end{array}$ & $\begin{array}{c}664 \\
(4)\end{array}$ & $\begin{array}{c}2,106 \\
(5)\end{array}$ & $\begin{array}{c}1,846 \\
(6)\end{array}$ & $\begin{array}{l}169 \\
(7)\end{array}$ & $\begin{array}{l}91 \\
(8)\end{array}$ \\
\hline
\end{tabular}

$\mathrm{T}$ statistics in parentheses. Also included in regressions are an intercept and dummy variables for the survey year.

Variable definitions. Job tenure: TEN $=13-9$ years, TEN2 $=\geq 10$ years. Education: $\mathrm{ED} 1=\leq 12$ years; $\mathrm{ED} 2=$ college graduate. City size: URB $1=>100,000$ people; URB2 $=<25,000$ people.

${ }^{a}$ WCHG4 is the percentage growth in real weekly wages between the base year and four years later.

* Significant at the 5 percent level (two-tailed test).

stayers grow 5.5 percent, compared to whites, in the four years after time zero: the relative changes are 1.3 percent and - 0.6 percent for quits and layoffs, respectively (both statistically significant). ${ }^{16}$ Layoffs hurt white women more than black women, and there are no clear racial differences for quitters and job stayers. For both voluntary and involuntary job leavers, nonwhites lose more (gain less) in the first post-separation year of employment than two years later. $^{17}$

16. These results are in general agreement with those of Boijas (1984), who shows that mobility is more harmful to blacks than whites. Blau and Kahn (1981a), on the other hand, find smaller post-layoff losses for nonwhites - a finding that may be due to the short post-layoff time period covered in Blau and Kahn's data. Regressions (not shown) on two-year wage growth indicate that laid-off blacks gain 10.7 percent in the first two years after the separation, relative to whites, but fail to maintain this initial improvement.

17. For nonwhite women, Blau and Kahn (198121) also find short-term losses but potential longterns gains following involuntary turnover. 
Mobility leads to large but mostly transitory losses for high-tenure men. For instance, between years zero and two (not shown), job changers with more than ten years preseparation tenure suffer earnings losses of almost 25 percent compared to their counterparts with three or fewer years seniority. Among job stayers the reduction is a much smaller 7.2 percent. This gap closes rapidly, and by year four, the loss to high-tenure job stayers (8.7 percent) actually exceeds that of persons quitting (4.4 percent) or laid off ( 4.5 percent) in year one.

Involuntary turnover has a similar impact on high-tenure women. The longest-tenure group loses almost 30 percent compared to the shortest-tenure group in the first two years after layoffs, but regains virtually all the lost ground in the next two years. Conversely, the relative decline following quits is both large and lasting - a further indication that quits benefit women less than men, especially those women with considerable preseparation tenure.

\section{PERSISTENCE}

Previous analysis of post-mobility earnings changes has usually concentrated on the years immediately following turnover. An important remaining question is whether separation-induced changes are transitory or permanent. Displacement that leads to short-term wage reductions may suggest a role for short- or medium-term government assistance during the adjustment period. On the other hand, displacement that forfeits substantial firm-specific investment or superior employer-employee matches would lead to losses of longer duration and could argue for worker retraining or placement programs. Similarly, quits are beneficial when they lead to permanent earnings increases, whereas transitory increases may indicate unfulfilled worker expectations of job improvement.

Earlier research investigating the duration of post-mobility earnings changes is limited and inconclusive. From an analysis of Social Security data, Jacobson (1984) found that 40 to 50 percent of job-changers' peak earnings reductions were eliminated after two years, and concluded that separation losses are mostly transitory. On the other hand, Podgursky and Swaim (1987), using the 1984 CPS displaced workers sample, argue that separation-induced wage losses persist over time. They also show that reemployment probabilities increase with the number of years following displacement, implying that some of the initial reduction in annual earnings gradually dissipates.

To see if initial reemployment conditions are an important predictor of future wage levels, I calculated the probability that wages fall in year four (three years after the separation) by 10 percent or more below year zero levels, conditional upon shortfalls in periods one and two (see Table 4). Initial reductions are defined as "small" if wages are less than 10 percent below base period earnings in both years one and two (column 1) and "large" if reduced more than 10 percent in either year (column 2). ${ }^{18}$

The results provide strong evidence that wage reductions are lasting. Earnings in year four that are at least 10 percent lower than year zero earnings are four times more likely for men, and two

18. Losses are likely to be largest in period one if separations occur early in that calendar year but in year two if the separation occurs later in the year, since, in the latter case, year one weekly wages will mainly reflect the higher earnings of the preseparation job. For this reason, initial losses are calculated as the maximum reduction in the two years following year zero. 
to four times more likely for women, when initial losses are "large" than when they are "small." "Very large" wage losses in year four (defined as earnings that are at least 25 percent below base year levels) are even more closely tied to initial experiences - almost six times more likely for men, and 5.1 times more likely for women, when similar reductions occur in early postseparation years. ${ }^{19}$

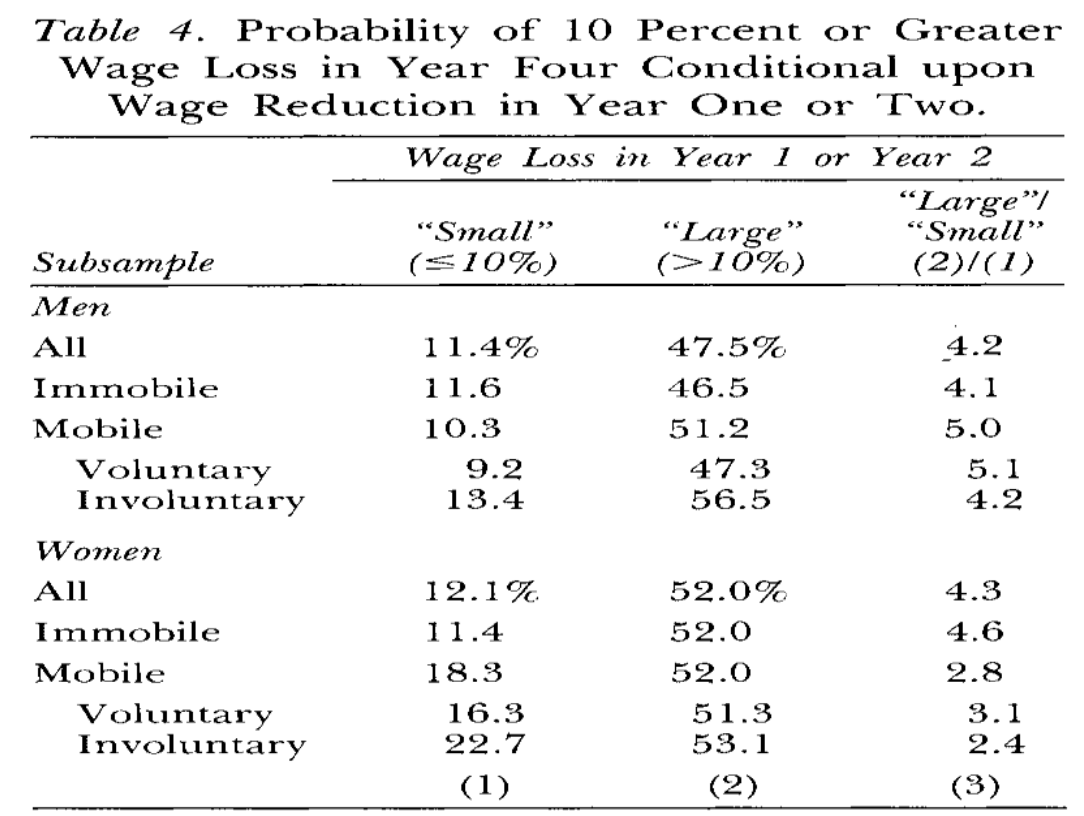

Wage losses are defined as "small" if wages were less than 10 percent below base period earnings in both years one and two and "large" if reduced by more than 10 percent in either year.

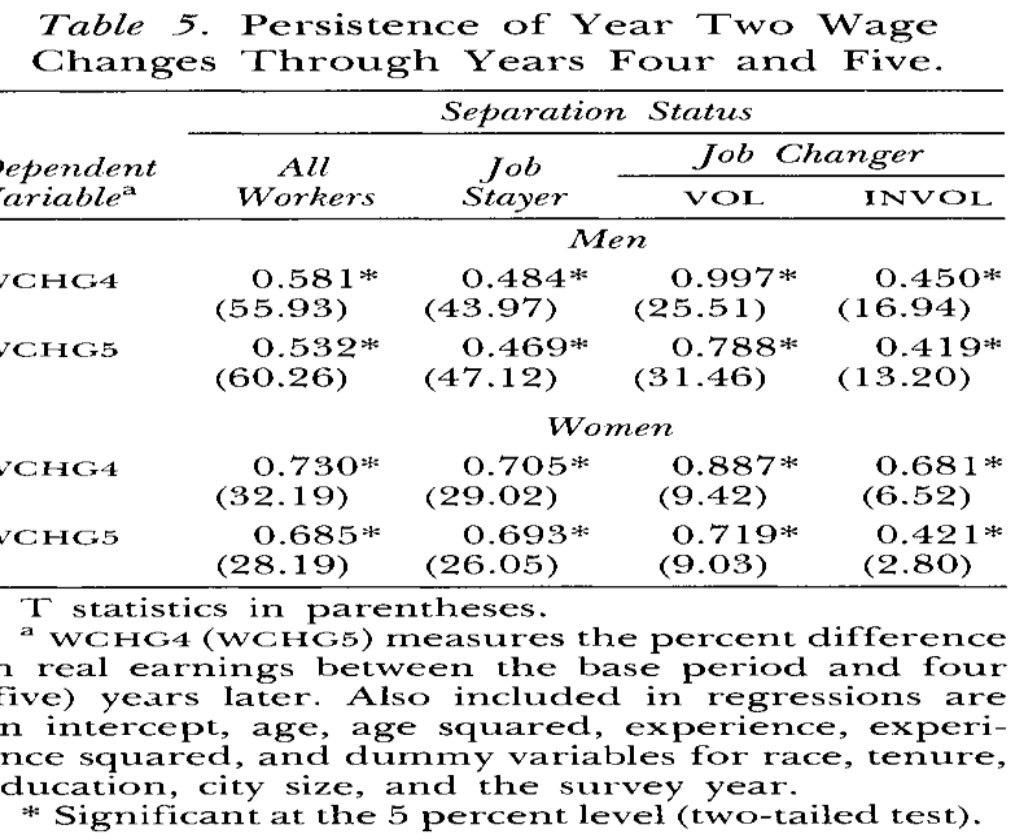

19. A table detailing these results is available on request. 
Further evidence on the correlation of earnings changes across time can be found from regressions of

$$
\mathrm{WCHGT}=\beta X_{0}+\gamma \mathrm{WCHG} 2+\epsilon_{\mathrm{t}} .
$$

The coefficient $\gamma$ is a measure of the persistence of post-separation wage changes, with a value of one implying complete continuation of initial changes through year four or five and a value of zero implying no persistence. $^{20}$

Table 5 shows regression estimates for $\gamma$ in equation (3). The coefficients always differ significantly from zero, with between 42 and 100 percent of year two wage changes lasting through periods four or five. For men, an average of 58 percent of the initial change continues through year four and 53 percent through year five. Among women, almost 70 percent of the wage change lasts through period five. Persistence of annual income changes is even stronger. In regressions (not shown) that substitute income for wages, the coefficient on $\gamma$ is higher than in the corresponding wage regression in all cases for men and in four of six cases for women.

Initial wage changes are most persistent following quits and least persistent after layoffs. For instance, 100 percent of year two wage changes continue into year four and almost four-fifths through year five for male quitters; among women, the corresponding proportions are 89 percent and 72 percent. The percentage of initial wage changes continuing through years four and five is smaller for laid-off workers (42-68 percent), but still sizable.

\section{REPEATED TURNOVER}

If stable employment is associated with good job matches and high levels of specific human capital investment, it is reasonable to anticipate that workers will experience more beneficial (or less adverse) consequences from changing jobs when they stay with their new position for at least a few years than when they quickly leave it. Stability and high earnings also go together when firms pay efficiency wages to reduce turnover or increase effort. Conversely, turnover will be high when jobs offer few opportunities for advancement or rewards for extra initiative.

Table 6 compares the wage growth of individuals staying on the same job in years 3-5 with the wage growth of those who change employment at some point during the three years. ${ }^{21}$ VOL and INVOL again show whether permanent separations occur in year one. NSEP, VSEP, and ISEP are dummy variables indicating job change at any point during years 3-5 for year one job stayers, quitters, and involuntary job changers, respectively.

As anticipated, future separations are associated with slower growth of weekly wages. Among men, the relationship is fairly strong for period one stayers and for involuntary changers, but much weaker for quitters. Subsequent mobility has virtually no impact on women who stay with their jobs in year one, but strongly reduces the wage growth of year one job changers. For

20. WCHG2 should not be interpreted as causing changes in WCHG4 or WCHG5.

21. Separations recorded in year two are not included because there is no way to determine whether they actually occur in that year or, instead, in year one, with unemployment following and persisting into year two. 
Table 6. Effect of Future or Multiple Separations on Wage Growth.

\begin{tabular}{lcccc}
\hline & \multicolumn{2}{c}{ Men } & \multicolumn{2}{c}{ Women } \\
\cline { 2 - 4 } \cline { 5 - 6 } Regressor & WCHG4 & WCHG5 & WCHG4 & WCHG5 \\
\hline NSEP & $-0.057^{*}$ & $-0.047^{*}$ & -0.004 & 0.022 \\
& $(-3.97)$ & $(-3.94)$ & $(-0.12)$ & $(0.71)$ \\
VOL & $0.078^{*}$ & $0.080^{*}$ & $0.199^{*}$ & 0.131 \\
& $(2.44)$ & $(3.01)$ & $(2.97)$ & $(1.88)$ \\
VSEP & 0.008 & -0.038 & $-0.324^{*}$ & $-0.224^{*}$ \\
& $(0.21)$ & $(1.13)$ & $(-3.68)$ & $(-2.49)$ \\
INVOL & $-0.132^{*}$ & $-0.088^{*}$ & 0.183 & 0.162 \\
\multirow{2}{*}{ ISEP } & $(-2.73)$ & $(-2.18)$ & $(1.64)$ & $(1.42)$ \\
& -0.038 & -0.084 & -0.193 & -0.188 \\
& $(-0.66)$ & $(-1.73)$ & $(-1.48)$ & $(-1.40)$ \\
& $(1)$ & $(2)$ & $(3)$ & $(4)$ \\
\hline
\end{tabular}

$T$ statistics in parentheses.

WCHG4 (WCHG5) measures the percent difference in real earnings between the base period and four (five) years later. Also included in regressions are an intercept, age, age squared, experience, experience squared, and dummy variables for race, tenure, education, city size, and the survey year.

* Significant at the five percent level (two-tailed test).

example, quits followed by stable employment lead to five-year earnings increases exceeding 13 percent, whereas quits followed by further job-leaving result in weekly wages falling an average of 8.8 percent. Similarly, wages grow over five years by 17.6 percent when layoffs are followed by stable work but fall 2.6 percent if there is additional job change.

Although mobility is most beneficial when the new employment leads to high job stability, dramatic differences are again apparent for men and women. Women gain from both voluntary and involuntary mobility, provided the new employment lasts for several years, but lose in both cases when further job change occurs. Men, on the other hand, gain from quits and lose from layoffs, regardless of future employment patterns, although subsequent stability does lead to somewhat faster wage growth. Thus, intra-firm advancement may be more important for women than men, and job shopping more important for men than women.

\section{GENDER VERSUS INCOME}

The most important of the differences between male and female heads of households is that women earn much less than men. In this sample, for example, the median weekly wage for men (\$208) is only slightly below the 90th percentile for women (\$216), and the 75th percentile for women (\$152) is barely higher than the 25th percentile for men (\$146). The gender group patterns described above may therefore be at least partly due to earnings differences. In particular, the legal minimum wage is more likely to present a barrier to downward wage adjustment for women than for men. 


\begin{tabular}{|c|c|c|c|c|}
\hline \multirow[b]{2}{*}{ Regressor } & \multicolumn{2}{|c|}{ Men } & \multicolumn{2}{|c|}{ Women } \\
\hline & (a) & (b) & (a) & (b) \\
\hline NSEP & & $\begin{array}{l}-0.052^{*} \\
(-5.25)\end{array}$ & & $\begin{array}{l}-0.086^{*} \\
(-3.80)\end{array}$ \\
\hline VOL & $\begin{array}{l}0.074^{*} \\
(4.96)\end{array}$ & $\begin{array}{l}0.069^{*} \\
(3.09)\end{array}$ & $\begin{array}{l}-0.114^{*} \\
-3.19)\end{array}$ & $\begin{array}{c}-0.090 \\
(-1.81)\end{array}$ \\
\hline VSEP & & $\begin{array}{l}-0.027 \\
(-0.96)\end{array}$ & & $\begin{array}{c}-0.107 \\
(-1.59)\end{array}$ \\
\hline INVOL & $\begin{array}{l}-0.107^{*} \\
(-5.40)\end{array}$ & $\begin{array}{l}-0.122 * \\
(-3.54)\end{array}$ & $\begin{array}{l}-0.241^{*} \\
(-4.61)\end{array}$ & $\begin{array}{l}-0.361 * \\
(-3.16)\end{array}$ \\
\hline ISEP & & $\begin{array}{c}-0.007 \\
(-0.18)\end{array}$ & & $\begin{array}{c}0.114 \\
(0.90)\end{array}$ \\
\hline \multirow[t]{2}{*}{$\mathbf{N}$} & \multicolumn{2}{|c|}{13,779} & \multicolumn{2}{|c|}{1,637} \\
\hline & (1) & (2) & (3) & (4) \\
\hline
\end{tabular}

\footnotetext{
$T$ statistics in parentheses.

${ }^{2}$ WCHG4 measures the percent difference in real earnings between the base period and four (five) years later. Also included in regressions are an intercept, age, age squared, experience, experience squared, and dummy variables for race, tenure, education, city size, and the survey year.

* Significant at the five percent level (two-tailed test).
}

This section investigates wage changes for workers whose preseparation real earnings exceed $\$ 67$ per week. The truncation point represents the average legal minimum weekly wage of fulltime workers during the period $1971-75 .^{22}$ Eliminating low-wage individuals reduces the female sample by a much greater proportion ( 22 percent) than it does the male sample ( 3 percent). Results of the regessions, with WCHG4 as the dependent variable, are shown in Table 7. Columns 1 and 3 control for year one separations, and columns 2 and 4 add dummy variables for subsequent turnover.

For men, the coefficients in Table 7 are very similar to the full sample results presented in Tables 3 and 6. Quits raise weekly wages, layoffs lower them, and subsequent turnover modestly reduces earnings growth. Excluding low-wage earners leads to much more dramatic changes for women. For example, whereas Table 3 shows that layoffs result in small earnings gains for all women, Table 7 indicates that among higher-income women, involuntary separations are associated with four- year wage reductions of over 21 percent. Similarly, the modest 2.6 percent gain from quits in Table 3 becomes a substantial 10.8 percent loss in Table 7 . Subsequent mobility again is associated with reductions in earnings for year one stayers and quitters but has a statistically nonsignificant positive impact on the earnings of involuntarily changers.

22. Thus, low-wage earners and most part-time workers are excluded. Various other truncation criteria were tried, without changing the major conclusions stated below. 
These findings reinforce the earlier conclusion that men gain more from voluntary mobility than do women. Further, in the absence of barriers to downward wage adjustment, they lose less from involuntary job change. The full sample results indicating modest post-layoff earnings increases for women are therefore dominated by the small reductions (or gains) among those previously working few hours or earning near the legal minimum wage. Post-turnover job stability is also most important for women with low preseparation earnings, suggesting that, as expected, low wages and employment instability frequently go together.

\section{PRESEPARATION WAGE GROWTH}

Job separations do not occur randomly. For instance, substantial investment in firm-specific skills is likely to simultaneously increase wage growth and reduce turnover probabilities, as are incentive-based contracts providing for deferred wage payments. Economic conditions in the sector of employment may also be important. Jobs in declining sectors are likely to have slowly growing or even falling wages and, to the extent the decline is believed to be permanent, high rates of turnover. On the other hand, when wages are determined by worker characteristics that are useful across a variety of jobs, there is less reason to expect wage growth and separation rates to be related. For example, wage profiles could depend mostly on the speed with which individuals "mature" as their careers progress.

If prior wage growth is strongly correlated with both turnover probabilities and expected future earnings change, in the absence of mobility, comparisons of wage increases experienced by job stayers and movers will yield biased estimates of separation effects. For example, if turnover occurs most frequently when pre-separation jobs have extremely flat wage profiles, mobility could raise wages even though the earnings of job leavers grow more slowly than those of stayers (since they would have risen even more slowly in the old job). To determine whether such a bias occurs, two equations are estimated. The first is

$$
\begin{gathered}
\text { GROW }=\beta_{1} \mathrm{X}_{0}+\beta_{2} \text { VOL } \\
+\beta_{3} \text { INVOL }+\epsilon,
\end{gathered}
$$

where GROw is the rate of wage change over the two years ending with year zero (GROW $=\left[\mathrm{W}_{0}-\right.$ $\left.\left.\mathrm{W}_{-2}\right] / \mathrm{W}_{-2}\right), X$ is the vector of control characteristics, and VOL and INVOL are dummy variables indicating year one separations. The coefficients $\beta_{2}$ and $\beta_{3}$ then show the relationship between rates of wage growth and future separations. Negative coefficients indicate that slow earnings growth increases the probability of future mobility, whereas positive values imply the opposite. ${ }^{23}$ The second equation is

$$
\text { WCHG4 }=\gamma_{1} X_{0}+\gamma_{2} \mathrm{GROW}+\epsilon,
$$

with $\gamma_{2}$ showing the association between prior and subsequent earnings growth.

Column 1 of Table 8 presents results of equation (4) and columns 2-5 the results of equation (5). Surprisingly, slow previous wage growth increases future turnover only for involuntary

23. An alternative approach used by Mincer (1986) is to compare the postseparation wage growth of year zero job leavers to the preseparation change of later movers. 
separations involving women. Preseparation wages grow a statistically insignificant 1-2 percent faster for male job leavers than for male job stayers and almost 7 percent more for female quitters than for immobile females. Conversely, prior wages grow much more slowly for women experiencing layoffs than for their immobile counterparts. Coefficients on GROW, in columns 25 , are negative and, except for layoffs of women, quite small, indicating that preseparation wage growth is a poor indicator of subsequent changes. ${ }^{24}$

Since slow weekly wage growth is associated with neither high turnover rates nor depressed subsequent earnings, it is unlikely that comparisons of the earnings changes of job stayers and leavers are seriously biased by endogeneity of the mobility decision. The one group that may be an exception is women laid off from high-paying jobs; how important the bias is in that case is a matter for further study.

\section{SUMMARY AND CONCLUSIONS}

The findings of this research suggest two primary conclusions. ${ }^{25}$ First, studies that concentrate on the average earnings changes of job changers may be misleading, given the extremely high variance of outcomes. Considerable dispersion is observed even after controlling for the source of mobility, with quits frequently leading to wage reductions and permanent layoffs sometimes leading to increases in income. Although a portion of the losses suffered by some groups of job changers (for example, many high-tenure men) is transitory, a substantial share of the initial wage change usually persists over several years.

These results highlight the need not only for public policies providing short- term assistance for job changes, but also for policies such as skill retaining and relocation assistance that facilitate transitions into new high-wage employment. This conclusion is reinforced by the finding here that mobility has more beneficial income consequences when it leads to stable subsequent employment than when it does not, and also by earlier related work (Ruhm 1987a) showing that recent job changers account for a disproportionate share of the reduction in aggregate employment levels that occurs during cyclical downturns.

Second, this analysis shows strong evidence of differential effects of mobility across race and gender. Although the wage differential between the whites and nonwhites declined during the sample period, relative earnings gains were largely restricted to nonwhite job stayers. Also, just as minorities are less able than whites to use mobility as a mechanism for job improvement, women are less likely than men to benefit from employment changes. Men gain more from quits and, where the legal minimum wage does not prevent downward adjustment, lose less from layoffs than women. Similarly, repeated turnover is less costly to men than women.

Further, this study has shown that the minimum wage floor presents a more effective barrier to downward wage adjustment for women than men, and involuntary layoffs can actually help some

24. Regressions on subsamples of men and women earning more than $\$ 67$ per week yield results generally similar to those in Table 8. The one important change is that the coefficient on GROW for laidoff women becomes positive and very large (0.723).

25. These conclusions are qualified by limitations in the data. In particular, the exclusion of non-household heads leads to the exclusion of a substantial proportion of the female labor force. Further work, with more comprehensive data sets, would clearly be desirable. 
Table 8. Impact of Previous Wage Growth on Subsequent Earnings and Mobility.

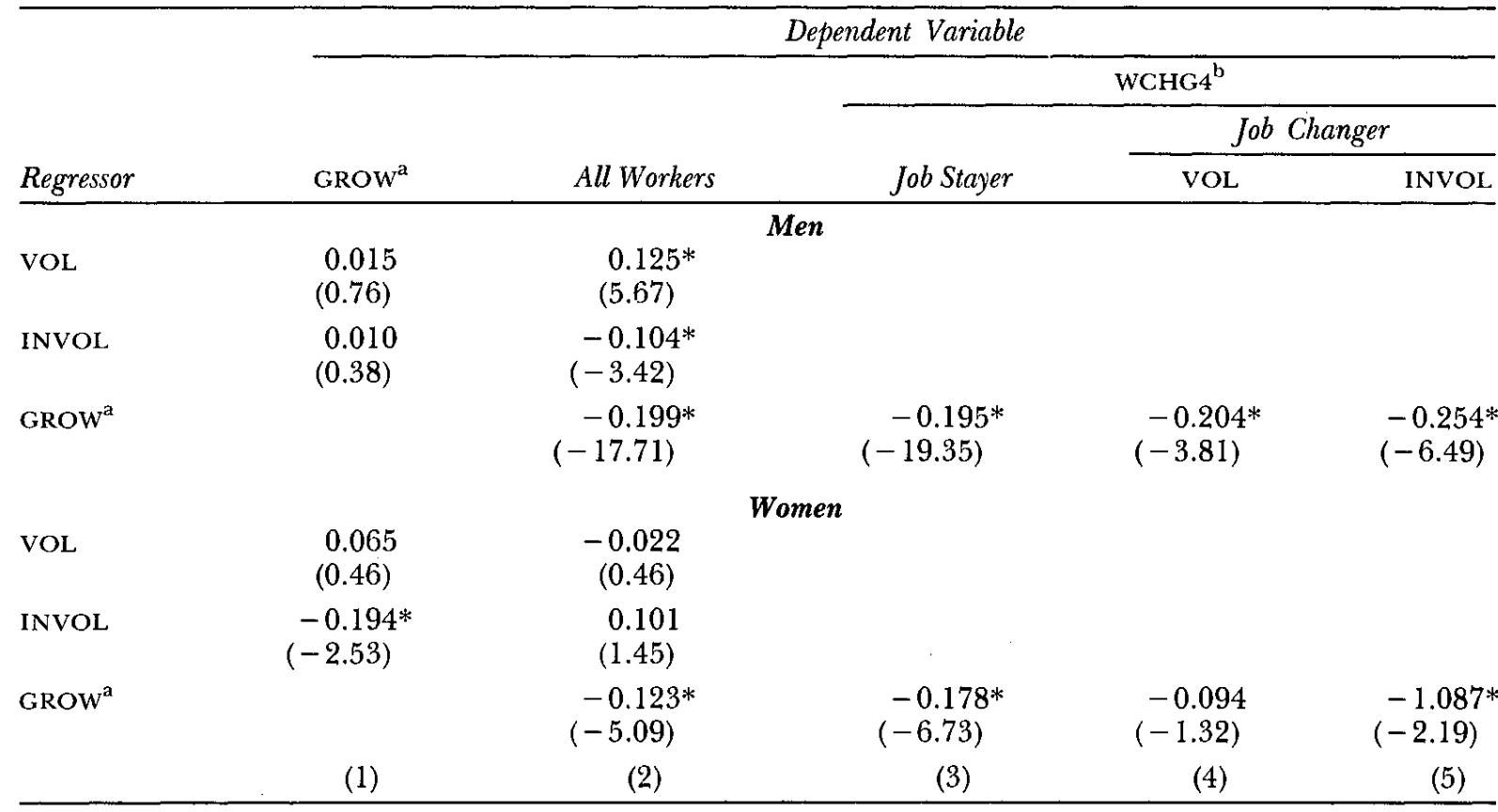

T statistics in parentheses.

${ }^{a}$ GROW indicates the percentage growth in real weekly wages during the two years prior to the base period.

${ }^{b}$ WCHG4 measures the percent difference in earnings between the base period and four years later.

Also included in regressions are an intercept, age, age squared, experience, experience squared, and dummy variables for race, tenure, education, city size, and the survey year.

* Significant at the 5 percent level (two-tailed test).

women to escape from low-wage dead-end jobs, provided they find stable subsequent employment. Conversely, women earning higher wages lose more from involuntary separations than men do, and, unlike men, do not gain from stability in their next job.

These findings provide strong evidence of labor market segmentation. In a purely competitive market, the mechanisms for job improvement should be similar for all types of workers. Instead, even among household heads with stable employment histories, white men benefit more from voluntary mobility and have greater returns to experience and seniority than do nonwhites and women. The significant gender differences indicate that the substantial existing body of research on the turnover of male workers has, at most, limited applicability to women. These gender differences also argue that government efforts to promote "equal opportunity" should continue and that programs targeted at disadvantaged groups (such as affirmative action) should not be weakened or eliminated until more efficient ways of promoting the same goals can be implemented.

\section{REFERENCES}

\section{Antel, John J.}

1985 "Costly Employment Contract Renegotiation and the Labor Mobility of Young Men." American Economic Review, Vol. 79, No. 5, pp. 976-91.

\section{Binder, Alan}

1973 "Wage Discrimination: Reduced Form and Structural Estimates." Journal of Human

Resources, Vol. 8, No. 4, pp. 436-55. 
Blau, Francine D., and Lawrence M. Kahn

1981a "The Causes and Consequences of Layoffs." Economic Inquiry, Vol. 19, No. 2, pp. 27095.

198 lb "Race and Sex Differentials in Quits by Young Workers." Industrial and Labor Relations Review, Vol. 34, No. 4, pp. 563-77.

Borjas, George J.

1984 "Race, Turnover, and Male Earnings." Industrial Relations, Vol. 2, No. 1, pp. 73-89.

Corcoran, Mary, and Greg J. Duncan

1979 "Work History, Labor Force Attachment, and Earnings Differences Between Races and Sexes." Journal of Human Resources, Vol. 14, No. 1, pp. 3-20.

Duncan, Greg J., and Saul Hoffman

1979 "On-the-Job Training and Earnings Differences by Race and Sex." Review of Economics and Statistics, Vol. 61, No. 4, pp. 594-603.

Freeman, Richard B.

1981 "Black Economic Progress After 1960: Who Has Gained and Why." In Sherwin Rosen, ed., Studies in Labor Markets. Chicago: University of Chicago Press, pp. 247-94.

1980 "The Facts About the Declining Economic Value of College." Journal of Human Resources, Vol. 15, No. 1, pp. 124-42.

Gottschalk, Peter, and Tim Maloney

1985 "Involuntary Terminations and Job Matching: A Test of Job Search Theory." Journal of Labor Economics, Vol. 3, No. 2, pp. 109-23.

Hamermesh, Daniel S.

1984 "The Human Capital Losses of Displaced Workers." Mimeo, Michigan State University. Hamermesh, Daniel S., and Albert Rees

1984 The Economics of Work and Pay. New York: Harper \& Row.

Jacobson, Louis S.

1984 "A Tale of Employment Decline in Two Cities: How Bad Was the Worst of Times?" Industrial and Labor Relations Review, Vol. 37, No. 4, pp. 557-69.

Jenkins, Glenn P., and Claude Montmarquette

1979 "Estimating the Private and Social Opportunity Costs of Displaced Workers." Review of Economics and Statistics, Vol. 61, No. 3, pp. 342-53.

Mincer, Jacob

1986 "Wage Changes in Job Changes." Mimeo, Columbia University.

Mincer, Jacob, Boyan and Jovanovic

1981 "Labor Mobility and Wages." In Sherwin Rosen, ed., Studies in Labor Markets. Chicago: University of Chicago Press, pp. 21-63.

Podgursky, Michael, and Paul Swaim

1987 "Job Displacement and Earnings Loss: Evidence from the Displaced Worker Survey." Industrial and Labor Relations Review, Vol. 41, No. 1, pp. 17-29.

Ruhm, Christopher J.

1987a "Job Tenure and Cyclical Changes in the Labor Market." Review of Economics and Statistics, Vol. 69, No. 2, pp. 372-78.

1987 b "The Extent and Persistence of Unemployment Following Permanent Quits and Layoffs." Department of Economics Working Paper No. 121, Boston University.

1986. "Heterogeneous Workers, Wages, and Labor Mobility." Mimeo, Boston University. 